\title{
Nestling and Fledgling Plumages of Cuculus saturatus horsfieldi and C. poliocephalus poliocephalus in Japan
}

\author{
Hiroyoshi Higuchi ${ }^{1,2}$ and Robert B. PAYNE ${ }^{2}$ \\ ${ }^{1}$ Laboratory of Forest Zoology, Faculty of Agriculture, The University of \\ Tokyo, Tokyo 113; ${ }^{2}$ Museum of Zoology and Department of Biolpgy, \\ The University of Michigan, Ann Arbor, Michigan 48109, U.S.A. \\ ツツドリとホトトギスの巣内雛および巣立ち雛の羽色 \\ 樋口広芳苂・ロバートB. ペイン2 \\ ${ }^{1}$ 東京大学農学部森林動物学教室; ${ }^{2}$ ミシガン大学動物学博物館
}

The Himalayan and Little Cuckoos, Cuculus saturatus and C. poliocephalus, are closely related species with very similar plumages (BECKING 1975). The juveniles of the two species are also similar in appearance. BAKER (1927) stated that the first plumage stage (probably nestling and.fledgling plumages) is nearly the same in both $C . s$. saturatus and C. p. poliocephalus of India.

The two species are represented by the subspecies $C$. s. horsfieldi and $C . p$. poliocephalus in Japan, where they are mostly sympatric. We have examined museum skins, live birds, and published photographs, and found that the nestlings and fledglings of these cuckoos can be distinguished rather easily by their plumages. Since the host species of these cuckoos appear to be partly shared in common (Kobayashi \& IsHizawa 1940), the differences in juvenile plumages will be helpful when investigating the relative degrees of parasitism of the two species on different hosts.

\section{MATERIALS}

C. s. horsfieldi. Four skins (Table 1), two live fledglings, and two photographs of fledglings were examined. They are all from central Honshu, the largest island of Japan. The two live fledglings were observed on Mt. Hakone, Kanagawa, on 3-5 July 1985. The two photographs in UchidA \& ShImomura (1931) and UchIDA (1949) were taken on Mt. Fuji, Shizuoka. The four live and photographed individuals were fostered by Crowned Willow Warblers Phylloscopus occipitalis, the main host of $C . s$. horsfieldi in Honshu (Kobayashi \& Ishizawa 1940, Kiyosu 1965, Royama 1963, Higuchi 1978). The host species for the four C. s. horsfieldi skins are not known.

C. p. poliocephalus. Three skins (Table 1) and 18 live nestlings (feathers grown) were examined. Fifteen of the 18 live young were observed in June-August 19841986 on Miyake-jima, in the Izu Islands (off central Honshu) where C. poliocephalus is the only breeding cuckoo species (HIGUCHI 1973). The other three were observed on 7-15 July 1985 on Mt. Futagoyama, Zushi, Kanagawa, central Honshu. Seventeen of a total of 21 individuals were fostered by Bush Warblers Cettia diphone, the 
Table 1. Specimens of young $C$. saturatus horsfieldi and $C$. poliocephalus poliocephalus from Japan.

\begin{tabular}{|c|c|c|c|c|c|c|c|c|}
\hline No. & Cat. No.* & Locality & Date & Sex & $\begin{array}{l}\text { Wing } \\
(\mathrm{mm})\end{array}$ & $\begin{array}{c}\text { Tail } \\
(\mathrm{mm})\end{array}$ & $\begin{array}{l}\text { Weight } \\
\text { (g) }\end{array}$ & Notes \\
\hline \multicolumn{9}{|c|}{ C. s. horsfieldi } \\
\hline 1 & YI 31008 & $\begin{array}{l}\text { Mt. Norikura, } \\
\text { Nagano }\end{array}$ & 18 July 1891 & - & 151 & 93 & - & Fledgling \\
\hline 2 & YI 25052 & $\begin{array}{l}\text { Mt. Fuji, } \\
\text { Shizuoka }\end{array}$ & 17 Aug. 1936 & $\delta$ & 140 & 85 & 55.1 & Fledgling \\
\hline 3 & YI 33364 & $\begin{array}{l}\text { Mt. Asama, } \\
\text { Gunma }\end{array}$ & 28 June 1943 & - & 116 & 50 & 75.0 & $\begin{array}{l}\text { Old nestling } \\
\text { or young } \\
\text { fledgling }\end{array}$ \\
\hline 4 & $\begin{array}{l}\mathrm{BM}(\mathrm{NH}) \\
1955.3 .228\end{array}$ & $\begin{array}{l}\text { Mt. Fuji, } \\
\text { Shizuoka }\end{array}$ & 17 June 1903 & $\delta$ & 109 & 50 & - & $\begin{array}{l}\text { Old nestling } \\
\text { or young } \\
\text { fledgling }\end{array}$ \\
\hline \multicolumn{9}{|c|}{ C. p. poliocephalus } \\
\hline 1 & YI 5644 & $\begin{array}{l}\text { Hachijo-jima, } \\
\text { Izu Is. }\end{array}$ & 9 Sep. 1929 & $\hat{o}$ & 118 & - & - & $\begin{array}{l}\text { Fledgling or } \\
\text { perhaps in- } \\
\text { dependent } \\
\text { young }\end{array}$ \\
\hline 2 & YI 5645 & $\begin{array}{l}\text { Hachijo-jima, } \\
\text { Izu Is. }\end{array}$ & 9 Aug. 1923 & $\delta$ & 89 & 49 & 25.1 & $\begin{array}{l}\text { Probably } \\
\text { fiedgling }\end{array}$ \\
\hline 3 & YI 5646 & $\begin{array}{l}\text { Hachijo-jima } \\
\text { Izu Is. }\end{array}$ & 4 Aug. 1923 & ô? & 72 & 20 & - & $\begin{array}{l}\text { Nestling rear- } \\
\text { ed by Bush } \\
\text { Warblers }\end{array}$ \\
\hline
\end{tabular}

* YI: Yamashina Institute for Ornithology; BM (NH): British Museum (Nat. Hist.).

main host of Little Cuckoos in Japan (Kobayashi \& Ishizawa 1940, KiYosu 1965; Roy ama 1963, Higuchi 1978). Two young on Miyake-jima were reared by Ijima's Willow Warblers Phylloscopus ijimae; the hosts of the other two on Hachijo-jima are not known.

\section{RESULTS AND DISCUSSION}

All eight nestling and fledgling $C$. $s$. horsfieldi were quite similar in general appearance (Fig. 1). The upper, throat, and breast plumage was dark blackish brown, and these feathers were faintly fringed with white. The ventral part was broadly banded with dark blackish brown and white, though the bars were obscure and much darker in nestlings.

In the four skins, Munsell code of the dark blackish brown plumage was 5.0YR 2.0/2.0 or 5.0YR3.0/2.0. The edge of the wing was almost white but with a few small black speckles. The tail was dark blackish brown with some white spots along the quill, and the tip of the tail was also white. Undertail coverts were white, banded with dark blackish brown. Some chestnut patches were found on the wing andtail feathers in three of the four skins (YI 31008, YI 25025, BM 1955.3.228). One skin (BM 1955.3.228) had two small white feathers on its head.

These features of plumage were consistent with those of the five young presumed to be Himalayan Cuckoos in central Hokkaido (the second largest northern island), where Little Cuckoos do not occur (Higuchi \& SATo 1984; see also WBSJ 1980 for the distribution). Among these five young, chestnut patches on the wing and tail 

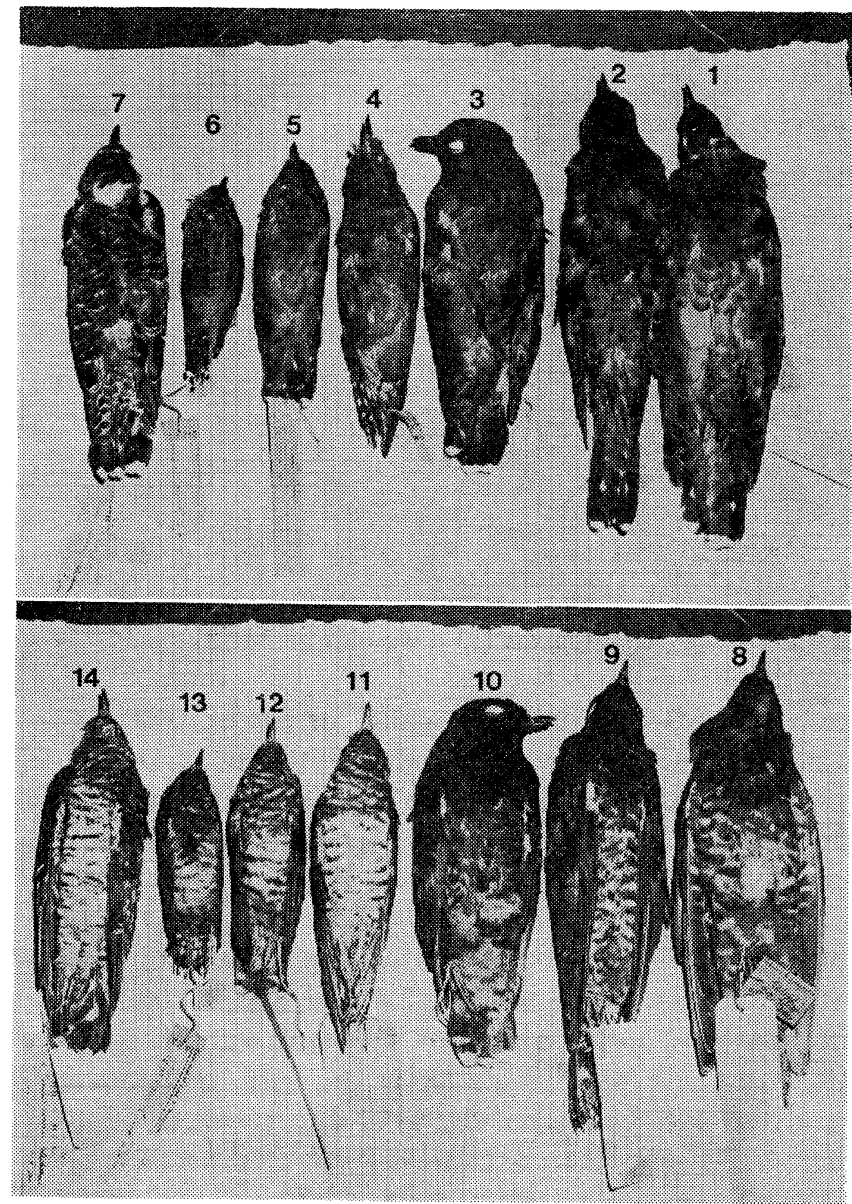

Fig. 1. Skins of nestlings or fledglings of C. saturatus horsfieldi $(1-3,8-10), C$. poliocephalus poliocephalus $(4-6,11-13)$, and $C$. canorus telephonus $(7,14)$ from central Japan (stored in the Yamashina Institute for Ornithology).

feathers were found in two individuals. White feathers were not observed on the heads of any individuals (Higuchi \& SATo 1984). These five young in Hokkaido were reared by Bush Warblers.

BECKING (1981) has described both light and dark phase nestling and fledgling $C$. s. saturatus in India. Light coloured specimens have whitish underparts heavily barred with dark chocolate brown and possess rufous red greater wing coverts, whereas in dark specimens the barring is far less conspicuous and the upperparts are much darker. The feathers of underparts and back of dark specimens are dark blackish brown with a white apical band. The dark individuals of this subspecies are similar in appearance to young C. s. horsfieldi in Japan, but have white apical bands on the feathers.

The 21 young $C . p$. poliocephlus had almost the same appearance. The upper plumage was slaty black (SB hereafter) in 14 individuals and dark blackish brown (DBB hereafetr) in the others, and the feathers were faintly fringed with white. This plumage was similar to that of C. s. horsfieldi (Fig. 1). The throat and breast were, 


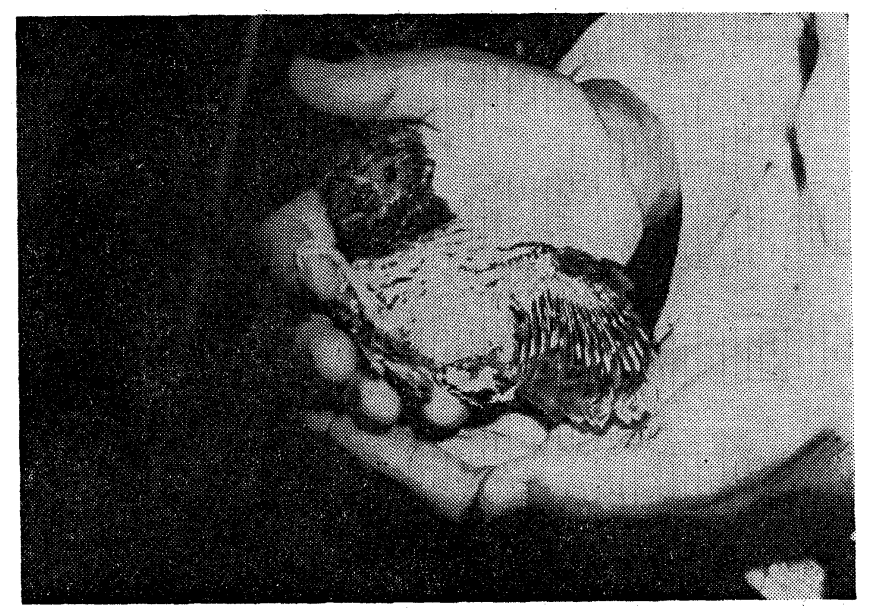

Fig. 2. A nestling C. p. poliocephalus (13 days old) on Miyake-jima, the Izu Islands.

however, banded with $\mathrm{SB}$ or $\mathrm{DBB}$ and white, or $\mathrm{SB}$ or $\mathrm{DBB}$ with irregular white speckles. The ventral part was white banded with SB or DBB. These bars were conspicuous from more than 10 days of age (Fig. 2). The lower parts of the young were much lighter than those of young C. s. horsfieldi, and more similar to those of young Common Cuckoos C. canorus (Fig. 1; see HiguchI \& SATo 1984 for the description of young Common Cuckoos).

In the three skins and six live young that were closely examined, Munsell code of the SB and DBB plumages was 5.0YR3.0/2.0 and 2.5YR4.0/0.5, respectively. The edge of the wing was obscurely banded or speckled with black and white. The tail was SB or DBB with some white spots along the quill, and the tip of the tail was also white, as in C. s. horsfieldi. The undertail coverts were white banded with SB or DBB, and their bars were clearer than those of C. s. horsfieldi.

From these descriptions, it is apparent that nestling and fledgling C. s. horsfieldi and $C . p$. poliocephalus can easily be distinguished by the plumages of the lower parts. It seems that the features of juvenile plumages in these Japanese cuckoos are not affected by locality and host, as shown in some cases of the present study.

The young $C$. s. horsfieldi and $C . p$. poliocephalus also differed in body size. Although comparable data are few, it is estimated from Table 1 and measurements of adults that young $C$. $s$. horsfieldi are 1.5-2.0 times the size of young $C$. p. poliocephalus at the fledged stage. The wing length and body weight of adults are 185-220 $\mathrm{mm}$ and $70.9-107.3 \mathrm{~g}$ in $C$. $s$. horsfieldi, and $150-163 \mathrm{~mm}$ and $42.4-59.6 \mathrm{~g}$ in $C$. $p$. poliocephalus, respectively (ЕNомото 1941).

It is suggested that the egg colour and parasitism rate of these cuckoos should be carefully investigated using juvenile plumage and body size as confirmation of identification. Some eggs ascribed to these cuckoos by earlier workers may have been wrongly identified, as has been suggested for Indian Cuckoos by BECKING (1981).

\section{ACKNOWLEDGMENTS}

We thank Akio Sasagawa, Ryozo Kakizawa (Yamashina Institute for Ornithology), and Graham Cowles (British Museum) for access to specimens, and Laura PAYNe and J. H. BeCKING for commenting on the draft. Field work was assisted by Masami HASEGAwA and Masahiko 
Yамамото. This work was supported in part by a grant-in-aid for the Special Research Project on the Biological Aspects of Optimal Strategy and Social Structure from the Japan Ministry of Education, Science, and Culture (Nos. 59215002 and 60107002).

\section{SUMMARY}

The upper plumage of nestling and fledgling C. saturatus horsfieldi and C. poliocephalus poliocephalus was similar, dark blackish brown (DBB) in the former and slaty black (SB) or DBB in the latter. The throat and breast were DBB in young $C$. s. horsfieldi, while they were banded with $\mathrm{SB}$ or $\mathrm{DBB}$ and white in young $C$. p p poliocephalus. The rest of the lower parts were banded with DBB or SB and white in both species, but the bars were obscure and much darker in nestling $C$. s. horsfieldi. The nestlings and fledglings of the two species in Japan are easily distinguished by the plumages of their underparts.

\section{摘要}

鉴内および巣立ち期の雛の羽色をツッドリ 8 個体, ホトトギス 21 個体で調査した. 得られた主な結 果は次のと郝りである.

1) ツッドリ雛の上面, 㗋と胸は黒に近い黑かっ色で, 各羽にかすかな白色羽縁がある. 腹面は黒 かっ色と白の横縞であるが, 策内雛ではその横縞が不明りょうで全体に黒っぽい. 翼縁はほとんど白 色.

2) ホトトギス雛の上面は, 灰黒色または黒かっ色をしており, 各羽にかすかな白色羽縁がある. 䐅と胸は灰黒色または黒かっ色と白の帯か, 灰黒色または黒かっ色地に不規則な白斑が混じる. 腹面 は白地に灰黑色または黒かっ色の横縞で, この横縞は巣内雛の時期からはっきりしている. 翼縁は黒 と白の不明瞭な帯あるいは斑になっている.

3）以上の結果から, 栄内および巣立ち期の 2 種の䧼は, 主に体下面の羽色によって容易に区別す ることができると言える.

\section{LITERATURE CITED}

BAKER, E. C. S., 1927. The fauna of British India: birds, 4. London, Taylor and Francis.

BECKING, J. H., 1975. New evidence of the specific affinity of Cuculus lepidus Müller. Ibis 117: 275-284.

1981. Notes on the breeding of Indian cuckoos. J. Bombay Nat. Hist. Soc. 78: 201-231.

ENomoto, K., 1941. A guide to wild birds. Osaka, Wild Bird Society of Japan Osaka chapter. (In Japanese.)

HiguchI, H., 1973. Birds of the Izu Islands. (1) Distribution and habitat of land and freshwater birds. Tori 22: 14-24. (In Japanese with English summary.)

1978. Ecology and evolution of birds. Tokyo, Shisakusha. (In Japanese.)

Higuchi, H., \& S. Sato, 1984. An example of character release in host selection and egg colour of cuckoos Cuculus spp. in Japan. Ibis 126: 398-404.

KiYosu, Y., 1965. The birds of Japan, 2. Tokyo, Kodansha. (In Japanese.)

Kobayashi, K., \& T. Ishizawa, 1940. The eggs of Japanese birds 2. Kobe, published by the authors.

Royama, T., 1963. Cuckoo hosts in Japan. Bird Study 10: 201-202.

UCHiDA, S., 1949. A lecture on ornithology. Tokyo, Akatsuki Shobo. (In Japanese.)

UChida, S., \& K. Shimomura, 1931. Photographs of bird-life in Japan, 2. Tokyo, Sanseido. (In Japanese and English.)

WBSJ (WILD Bird SocieTY of JAPAN), 1980. The breeding bird survey in Japan 1978. Tokyo, Wild Bird Society of Japan. (In Japanese.)

(Received 30 October 1986) 